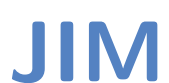

ISSN: 2183-0606

(CC BY 3.0)

Vol. 9, 4 (2021)

p. $29-57$

AM: May $/ 2021$

SM: May $/ 2020$

\title{
Choosing Between Innovative and Traditional Payment Systems: An Empirical Analysis of European Trends
}

\author{
Silvio John Camilleri ${ }^{1}$ and Christabelle Agius ${ }^{2}$ \\ ${ }^{1}$ Banking and Finance Dept., FEMA, University of Malta, Malta. | Silvio.j.camilleri@um.edu.mt \\ ${ }^{2}$ Banking and Finance Dept., FEMA, University of Malta, Malta. | christabelle.agius@gmail.com
}

\begin{abstract}
The current variety of payment methods offers faster settlements and reasonable security, however payment innovations may be met with inertia or resistance. This study addresses the characteristics which may be associated with the adoption of relatively novel payment systems and salient user trends in this respect. We investigate whether the reliance on traditional payment methods across European countries is related to socio-economic aspects, and also delve into the payment habits at the individual level. Results from an econometric model suggest that financial market development and education-related factors are negatively related to the use of traditional payment instruments. When considering consumer payment habits and awareness about novel facilities, particular differences across generations emerged. Cash and debit cards are most widely used and it seems that such choices are related to perceived convenience rather than due to aversion towards novel systems.
\end{abstract}

Keywords: Consumer Payment Behaviour; Europe; Innovation Adoption; Malta; Payment Instruments Use; Payment.

Cite paper as: Camilleri, S.J., Agius, C., (2021). Choosing Between Innovative and Traditional Payment Systems: An Empirical Analysis of European Trends, Journal of Innovation Management, 9(4), 29-57.; DOI: https://doi.org/10.24840/2183-0606_009.004_0003

\section{Introduction}

Throughout the last decades, retail and wholesale payments were revolutionised by a stream of novel systems, which proved particularly relevant in settling new types of business such as online transactions (Dahlberg et al., 2008; Humphrey, 2004; Khan et al., 2017). Particular payment methods were augmented by the availability of new technology such as improved internet connectivity and the diffusion of smartphones. These payment innovations may offer the potential of quicker and reasonably secure methods of settlement, thereby cutting business costs and raising efficiency (Hasan et al., 2012). With the introduction of novel systems such as blockchain, payment instruments may be expected to evolve further, and therefore knowledge about adoption and usage trends remains a research priority due to the implications on the financial industry, settlement costs, and policy-making (Handayani et al., 2020; Zhu and Fu, 2020).

While the ensuing choice of payment methods may offer added benefits to users, select consumers and possibly businesses may be reluctant to adopt such innovations and may even find it difficult to reduce their reliance on cash. Therefore, a better understanding of the characteristics which may be associated with the adoption of novel payment systems and their cost effectiveness is beneficial to policy-makers, regulators and socio-economic researchers (Dennehy and Sammon, 
2015). Unfortunately, research about the payment choices is rather limited (Frame and White, 2004; Apanasevic et al., 2018) and whilst the existing studies have often focused on the measurement of the rates of use and diffusion of various payment systems, the factors that may be associated with their adoption were less scrutinised or else considered in the context of one particular payment instrument.

It is the intention of this study to contribute towards addressing the above research lacuna. In particular the main aim of this paper is to explore the transition in the usage of salient payment methods from a socio-economic point of view. We do this through two main empirical tasks. Firstly we investigate whether the adoption of novel payment methods across countries is related to the inherent socio-economic characteristics. In particular, we consider the EU-wide differences in terms of the degree to which various countries rely on relatively traditional payment methods such as cheques and ATMs, as opposed to the use of more innovative systems such as internet or mobile payments. The cross-sectional variation is modelled as a function of a range of variables representing salient characteristics of the sampled countries. We then consider the payment trends at the individual level in terms of the personal choices of payment instruments and the likelihood of future adoption of alternative methods. In this respect, we conducted a questionnaire among ninety respondents, to obtain an insight into the typical payment habits and the attitudes towards various payment instruments.

Whereas the questionnaire is intended to capture the outlooks of individuals, the econometric model makes extensive use of economic data, and therefore it emphasises the business-related tendencies associated with payment instruments. In this way these distinct empirical tasks are expected to offer complementary insights. An additional worth of this paper is that we do not restrict our analysis to one particular payment instrument but rather focus on the general reliance on relatively traditional payment instruments as opposed to innovative ones. In this way, we expect our results to be of a more generalisable nature, and this is important in view of the fact that payment methods are likely to keep on evolving as new technologies such as blockchain become increasingly diffused.

The paper is structured as follows: Section 2 offers a review of prior literature and the subsequent section describes the methodology. Section 4 outlines the data and the empirical results of an econometric model which explains the cross-country variation in the use of traditional payment instruments across the EU. Section 5 presents the insights of a questionnaire intended to capture salient trends in payment habits at the individual level. Section 6 offers a discussion of the main empirical insights, while section 7 concludes.

\section{Contextual Background and Prior Literature}

This section offers a summary of the main trends which were witnessed in the use of salient payment systems over the past decades, as well as the factors which may contribute towards or dissuade from the adoption of different payment mechanisms. The choice of payment methods has flourished and this was fostered by the requisites of efficient payment services to complement e-commerce (OECD, 2006), the globalisation trend which has significantly altered financial market structures (Camilleri, 2006), and the tendency for the novel payment systems to use readily available infrastructures such as internet and mobile phones (Levitin, 2007). These trends have resulted in increased competition in this sector, as non-bank entities offering different kinds of retail payment methods stepped in to compete with financial institutions (Heng, 2007). While the latter enjoy substantial goodwill, the payment systems offered by non-bank providers tend to be more straightforward in the sense that they do not involve the burdens associated with opening a 
bank account (González, 2004).

The diffusion of novel payment systems depends on a client base of both businesses and retail consumers. Whilst most literature tended to focus on the adoption of payment systems from the point of view of consumers, the attitudes of businesses seem to be less well researched. Harris et al. (2011) studied the outlooks of a sample of Malaysian firms and found that entities are more likely to accept electronic payment systems when the perceived functionality, privacy, and security are deemed adequate. Costs are likely to play an important role as well, and these may involve the outlay of investing in a new payment system, as well as specific fees which may be charged by the service provider - for instance credit card transaction fees (Chakravorti, 2003).

Retail customers often tend to stick to existing habits and in order to adopt new payment methods they would typically require reassurance that the change will offer reasonable security, efficiency and convenience. Indeed, when customers feel well-served through the existing methods, they may be reluctant to adopt novel payment systems (Harasim and Klimontowicz, 2013). This underscores the importance that service providers offer a quality service and related information in order to foster the use of new payment products (Zhou, 2013).

Due to the economy-wide implications and the diversity of novel payment methods, various academic studies analysed the trends relating to the adoption and actual use of such instruments. As per the Diffusion of Innovations Framework (Rogers, 1983) innovations are first adopted by a restricted number of people who depending on their level of satisfaction, influence further potentialadopters to use the service. Further insights relating to the proliferation of novel technology include the Technology Acceptance Model (Davis, 1989) which features the perceived ease of use and perceived usefulness as main determinants of innovation acceptance. Additional factors such as individual differences and attitudes (Gefen and Straub, 1997; Venkatesh and Morris, 2000) were subsequently investigated. As further research specifically targeted the adoption of new payment systems, particular concepts emerged as consistently important. These include perceived risk, security issues, trust, demographic factors, IT literacy, social influences, perceived usefulness, confidentiality, speed and convenience, simplicity of use, and costs as outlined below.

a) Perceived Risk: As outlined by $\mathrm{Ho}$ and $\mathrm{Ng}$ (1994), the concept of risk in payments systems encompasses various dimensions as follows:

- Physical risk, such as the loss of cash or cards;

- Performance risk, which compromises the completion and settlement of a transaction;

- Psychological risk when frustration is experienced due to a transaction delay and the resulting postponed consumption;

- Financial loss risk due to the inability to obtain a deserved refund; and

- Time-loss risk when the completion of a transaction is delayed.

Stone and Gronhaug (1993) reported that different people perceive risk in different ways and Koenig-Lewis et al. (2015) found that perceived risk may be reduced by social influence and perceived enjoyment. Slade et al. (2015) observed that perceived risk was a significant factor which shaped the intentions to adopt remote mobile payments in the UK.

b) Security Issues: In the context of personal finance, the potential for losses emanating from fraud or hacking is an important aspect, given that a lifetime of savings may be at stake. Security risks may include unauthorised use, errors, lack of transaction records, and the compromising of privacy amongst other aspects (Mallat, 2007). Siau et al. (2004) identified security shortcomings as a significant hurdle in the adoption of e-commerce transactions, while Aigbe and Akpojaro (2014) contended that the future growth of e-commerce and related payment services is dependent on the security features. Arango et al. (2012) reported that security is a top factor which influences the choice of payment instruments at retail level. Despite the improvements in technology, security 
problems still remain (Sumanjeet, 2009) and these shortcomings should be addressed in order to convince consumers that e-payment transactions are reasonably safe (Tsiakis and Sthephanides, 2005; Kousaridas et al., 2008; Kim et al., 2010a).

Security emerged as the most important factor which impacts on the tendency to use mobile payments in a study by Shin et al. (2014) which focused on US and Korea. Similar results were reported by Khalilzadeh et al. (2017) in an online survey conducted among restaurant patrons.

c) Trust: Trust proved an important determinant which influenced the adoption of payment services such as mobile banking in studies by Lu et al. (2011) and Oliveira et al. (2014), yet it proved insignificant in a study by Teoh et al. (2013) which focused on the factors that influence the opinions about electronic payment systems amongst Malaysian consumers.

Maqableh et al. (2015), investigated trust attitudes across 214 survey respondents from Jordan vis-à-vis different payment methods. They reported that trust was positively related to reputation, security, familiarity, and ease of use, while other characteristics such as privacy and usefulness did not have a significant impact. A survey by Camilleri et al. (2013) among Maltese bank customers indicated that the degree of trust in internet banking services across users of the service was substantially higher than that of non-users.

d) Demographic Factors: Various studies suggest that younger persons are more likely to adopt novel technologies (Zeithaml and Gilly, 1987; Trocchia and Janda, 2000) and similarly innovations are more likely to be adopted by people who attained a higher level of education and earn more income (Jayawardhena and Foley, 2000; Lee and Lee, 2000; Buszko et al., 2019).

Demographics may influence the likelihood to use cash; for instance Arango et al. (2012) reported that elder people use cash for $59 \%$ of their transactions, while this statistic falls to $48.9 \%$ in case of younger persons. Demographics such as age and education were found to impact on the likelihood of adopting debit / credit cards (Carow and Staten, 1999; Borzekowski et al., 2008; Zinman, 2009).

In the context of internet banking, authors such as Polatoglu et al. (2001), Black et al. (2002), Karjaluoto et al. (2002), and Waite and Harrison (2004) reported that adoption rates are higher among younger generations whereas elder people tend to raise more concerns regarding inherent security issues (Camilleri et al., 2013). Internet banking services are more likely to be used by people attaining a higher level of education (Laforet and Li, 2005; Huam et al., 2008; Mirza et al., 2009).

Males and females may differ in their attitudes towards financial affairs and payment systems. Liébana-Cabanillas et al. (2014a) reported significant gender differences in the attitude towards mobile payments, whereas Köse and Güleryüz (2020) found that Turkish males are more likely to use internet banking than females. In addition, prior literature indicates that females may allocate higher importance on ancillary issues such as privacy (Shergill and Li, 2005). At a more general level, Barber and Odean (2001) and Bengtsson et al. (2005) reported differences across genders in terms of the management of financial affairs and personal objectives.

Demographic characteristics may also be extended to race and countries of origin. Cho (2008) studied the attitudes towards mobile commerce in the U.S. and Korea and reported that salient factors such as price seemed more significant among Korean respondents as compared to US ones. Zhou et al. (2012) used moderator analysis and found that culture may affect mobile commerce adoption. On the contrary, Lee and Lee (2000) did not find any differences across minority groups in their likelihood to adopt direct bill payment services.

The influence of demographics could be associated with the different habits across demographic groups. Research by Harasim and Klimontowicz (2013) which investigated the adoption of retail payment systems among Polish consumers suggested that as people form habits through their 
daily experiences, they tend to become reluctant to change such habits and would require tangible incentives in order to consider migrating towards different payment systems. For instance Pope et al. (2011) reported that the adoption rate of mobile payments in the US was hindered by the fact that consumers felt adequately served through the payment systems which they habitually used such as debit and credit cards. Similarly, a study by Camilleri et al. (2013) reported that non-adopters of internet banking were more satisfied with the traditional methods of delivery via bank branches as compared to internet banking users.

e) IT Literacy: The fact that demographics proved an important determinant in explaining the attitudes of customers towards novel payment systems, may be partly due to the inherent differences in IT literacy across demographic groups. Indeed, literature has pointed at the importance of the 'digital divide' since IT-oriented persons tend to be more prone to adopt new payment systems and electronic commerce (Porter, 2001).

f) Social Influences: Various authors have reported that social influence shaped the intention to adopt services such as mobile payments and this evidence spans across various countries (Chung, Stoel, Xu, \& Ren, 2012; Liébana-Cabanillas et al., 2014b; Musa et al., 2015). Such tendency may not be surprising given that mobile banking services are offered within the context of online networks, which also serve as a framework where people communicate and influence each other. Yang et al. (2012) confirmed that social influence is a significant determinant of the adoption mobile payment services in China, yet its impact on consumers' intentions varies across different stages.

Mehrad and Mohammadi (2017) investigated the effects of word of mouth communications in the context of the adoption of mobile banking in Iran, and confirmed that this factor impacts on the perceived ease of use, perceived usefulness, trust, and the intention to continue using the service. Al-Tarawneh (2016) reported that social influence shaped the intention to adopt online banking services in Jordan, although this insight was not confirmed by Alalwan et al. (2018) who investigated the adoption of internet banking within the same country. At a broader level, recommendations from acquaintances influence the choice of a financial services provider (World Economic Forum, 2013; Camilleri and Ellul, 2017).

g) Perceived Usefulness: Perceived usefulness proved a significant determinant of the likelihood to adopt internet banking (Lederer et al., 2000; Chi et al., 2007) and mobile payment systems (Mallat, 2007; Wessels and Drennan, 2010; Zarmpou et al., 2012; Liébana-Cabanillas et al., 2014b). Dahlberg et al. (2008) argued that novel payment systems ought to offer significant advantages which are not available in traditional payment services, in order to enhance the proliferation of the newer services. Distinguishing between genders, Riquelme and Rios (2010) found that when considering whether to adopt internet banking, males place a higher emphasis on perceived usefulness as compared to females.

h) Confidentiality: Prior studies such as Stewart and Segars (2002), Suh and Han (2003), Hwang et al. (2007) and George (2018) indicated that concerns about privacy and confidentiality may dissuade consumers from adopting electronic or online payment systems.

i) Speed and Convenience: Speed of settlement may also prove an additional factor which impacts on the adoption and the use of different payment systems (Jonker, 2005; Mallat, 2007). Sorkin (2002) reported that speed and convenience are particularly important from the point of view of online auction participants, whereas factors such as transaction-related risks are less important in this market segment.

j) Simplicity of Use: Ease of use is an important determinant of the adoption of new payment services (Arango et al., 2012) and consumers may be reluctant to migrate towards novel payment systems due to the perceived complexities. The latter perceptions may be formed as a result of 
lengthy registration procedures, complex instructions, or the resulting burden of managing separate accounts (Mallat, 2007). According to Laukkanen and Lauronen (2005), perceived complexity hindered the adoption of electronic services such as smart cards and mobile payments and similar results were reported by Mallat (2007) in the context of the adoption of mobile payment services across different focus groups. Indeed, studies such as Gounaris and Koritos (2008), Eriksson et al. (2005) and Abu-Assi et al. (2014) reported a positive relationship between perceived ease of use and the likelihood of adopting internet banking. Camilleri and Grech (2017) reported that the most important factor which would encourage people to adopt internet banking services would be simpler website navigation, while Chong et al. (2010) found that perceived complexity may be alleviated by user-friendly interfaces. Similar trends were reported in research which focused on the adoption of other technologies such as e-government services (Al-Hujran et al., 2015).

Ease of use is inversely related to the degree of effort which adopters have to go through when using a novel technology. Effort expectancy was found to be an important factor which impacted on the intention to adopt mobile banking services (Al-Tarawneh, 2016; Alalwan et al., 2017) and internet banking (Alalwan et al., 2018).

k) Cost Aspects: Costs are an additional determinant of the payment method selection, although research results are not consistent in terms of the relative costs associated with separate instruments (Shampine, 2007; Hayashi and Keeton, 2012). Electronic payment methods tend to be less costly than traditional paper-based ones given that they use minimum tangible resources and exploit the vast potential for economies of scale (Humphrey et al., 2001; Humphrey et al., 2003; Guibourg and Segendorff, 2007).

The nature of costs may differ across payment instruments; for instance interest is charged in case of credit cards whereas consumers may be required to maintain balances in non-interest earning bank accounts in order access particular payment methods (Zinman, 2007; Telyukova and Wright, 2008). At a broader level, the costs associated with different payment methods may include elements of transaction fees charged by service providers, interest expenses, and the possible costs associated with security shortcomings such as potential theft (ten Raa and Shestalova, 2004).

Not all empirical results converge on allocating a top priority to cost issues. In particular, Abrahão et al. (2016) focused on mobile payment adoption in Brazil and found that expected cost was not a statistically significant determinant. Finally, costs may also be considered from a broader societal point of view. For instance, Rivera (2019) argues that a cashless society may give rise to increased incidence of underground financing and may also proliferate types of crime which are harder to track.

Whilst one may expect that the above characteristics are to some degree influential across the adoption of payment methods in general, there are additional factors which are instrumentspecific. For instance the proliferation of mobile phone devices and related technical know-how has augmented the adoption of mobile payment systems (Paunov and Vickery, 2006; Kim et al., 2010b). Conversely, the perceived convenience of mobile payments may be hampered by technical constraints such as small screens sizes (Zhou, 2013).

Payment cards boast of reasonable security and convenience owing to their universal acceptability (Khan et al., 2017). The typical time lag between the purchase and the actual payment when using a credit card, may encourage additional use of such instruments and possibly increased spending (Bar-Gill, 2004). However, research by Arango et al. (2012) suggests that curtailing overspending ranks rather low in terms of the overall importance when choosing a payment instrument.

In this study we do not limit ourselves to consider one particular payment service as was often 
the case in prior literature. In particular, we focus on the overall factors which may be associated with the tendencies to adopt novel payment instruments or to rely on traditional methods. We feel that this approach is particularly important since whereas the most innovative payment methods are likely to change over time, the attitudes of consumers towards change may be less fluid. Therefore, as fintech alters the existing payment methods even further, we would expect our insights to remain relevant in interpreting salient trends which are likely to prevail in the near future. An additional worth of this study is that we do not limit ourselves to analyse factors associated with individual behaviour, but also consider economy-wide data which is more likely to capture the salient trends associated with business decisions regarding the choice of payment methods.

\section{Methodology}

In investigating the socio-economic characteristics which may impact on a country's likelihood to adopt innovative payment methods, we estimated an econometric model using a sample of twenty-eight European countries. In addition we conducted a questionnaire among 90 respondents based in Malta in order to obtain an insight into payment habits of users at the individual level.

\subsection{Econometric Model}

The aim of the econometric model was to account for the cross-sectional variation of the sampled countries, in terms of their reliance on relatively traditional payment methods in contrast to the use of more recent systems. The dependent variable for the respective countries was an indicator which took into account the use of cheques and ATMs as relatively outmoded payment instruments as opposed to online and mobile payments (Appendix A). This yardstick was then regressed over a set of explanatory variables that represented gender, age, employment, educational attainment, technological progress, and cross-border trade. A series of regressions was estimated, with explanatory variables being added or omitted depending on their statistical significance and the explanatory power of the overall models. Further details about the data and estimations are shown in Section 4.

\subsection{Questionnaire}

The questionnaire was conducted in order to obtain a perspective which complements the insights attained through the econometric model. In particular, this survey was intended to capture people's attitudes and usage patterns in relation to a variety of payment methods, and the likelihood of shifting to a different payment method in the near future.

Participants were chosen in no pre-set way by handing out 90 printed copies of the questionnaire to Maltese bank customers. Our choice of country was mainly due to the scant volume of research focusing on Malta. Indeed, as argued by Dahlberg et al. (2008) different countries have their own ingrained payment habits, and therefore attaining evidence in respect of a wider variety of countries (as opposed to the prevalent tendency to rely on observations gleaned from larger states) is important to complete a more coherent picture of cross-country variations.

Questionnaires were handed out to customers who were near bank branches in Valletta. Given that the latter is the main city, there was a cross-section of people from different locations throughout the Maltese islands and respondents were assisted to fill in the questionnaires when so needed. We opted for such an approach in order to capture responses from a diverse sample of people with differing characteristics such as age categories, employment and educational background. We did not administer an online questionnaire since this would have made it only 
accessible to IT-literate people. Before distributing the questionnaires, a pilot study was conducted amongst ten respondents using an earlier draft. Following the reactions to the pilot survey, the terminology was amended to improve clarity. The final copy of the questionnaire is shown in Appendix $B$ and the main insights are presented in Section 5.

\section{Econometric Findings: Likelihood of Using Traditional Payment Instruments}

In this section we present the results of an econometric model where a quantitative indicator of the reliance on traditional payment instruments was regressed over a set of socio-economic characteristics, using a sample of twenty-eight European countries in order to test for significant relationships. 1

In order to compile a variable that proxies the reliance on traditional payment channels as opposed to more innovative ones, we combined data relating to the use of cheques, ATMs, and the (lack of) use of more recent online/mobile payment systems. The cross-sectional data relating to the respective payment systems were sampled as at 2017 and the process through which these were aggregated in one indicator is detailed in Appendix A. The economic and demographic variables used as regressors described underneath were sampled as at the same year (Table 1 ).

Table 1. Summary of the Explanatory Variables

\begin{tabular}{|c|c|c|c|c|}
\hline & Variable 1 & Variable 2 & Variable 3 & Variable 4 \\
\hline Gender & $\begin{array}{l}\text { Population, male (\% } \\
\text { of total) }\end{array}$ & & & \\
\hline Age & $\begin{array}{l}\text { Population ages } \\
20-39(\% \text { of total) }\end{array}$ & $\begin{array}{l}\text { Population ages } \\
15-64(\% \text { of total })\end{array}$ & & \\
\hline Employment & $\begin{array}{l}\text { Employment to } \\
\text { population ratio, } \\
15+, \text { total }(\%)\end{array}$ & $\begin{array}{l}\text { Employment rate, } \\
\text { age group } 20-64(\% \\
\text { of total) }\end{array}$ & & \\
\hline Education & $\begin{array}{l}\text { Tertiary education } \\
\text { enrolment rate gross } \\
\%\end{array}$ & $\begin{array}{l}\text { Tertiary educational } \\
\text { attainment, age } \\
\text { group 30-34 (\%) }\end{array}$ & & \\
\hline Technology & $\begin{array}{l}\text { Availability of latest } \\
\text { technologies }\end{array}$ & $\begin{array}{l}\text { Government } \\
\text { procurement of } \\
\text { advanced technology } \\
\text { products }\end{array}$ & $\begin{array}{l}\text { Financial market } \\
\text { development }\end{array}$ & $\begin{array}{l}\text { Internet users } \\
\% \text { population }\end{array}$ \\
\hline Imports & $\begin{array}{l}\text { Imports of goods } \\
\text { and services ( } \% \text { of } \\
\text { GDP) }\end{array}$ & & & \\
\hline
\end{tabular}

The above variables were used as regressors in the econometric model which explains

the cross-country variation in the reliance on traditional payment systems.

The first explanatory variable was the percentage of males out of the total residents of each country in order to account for gender differences as noted in prior literature summarised above. The gender percentages were sourced from World Bank Open Data.

The second set of possible variables captured the age-structure of the population. Two

1. The sampled countries were: Austria, Belgium, Bulgaria, Croatia, Cyprus, Czech Republic, Denmark, Estonia, Finland, France, Germany, Greece, Hungary, Ireland, Italy, Latvia, Lithuania, Luxembourg, Malta, Netherlands, Poland, Portugal, Romania, Slovakia, Slovenia, Spain, Sweden, and United Kingdom. 
age-bracket indicators were chosen: percentage of people aged between 15 and 64 and percentage of people aged between 20 to 39 as obtained from World Bank Open Data. In case of people aged between 15 and 64, these are more likely to be gainfully employed and / or raised in a technology-oriented environment and are therefore more likely to be well-versed with innovative payment methods. As for the population aged between 20 to 39, this sector may expected to be more technology-savvy and therefore less prone to use traditional payment methods as compared to elders.

The third group of explanatory variables focused on employment, since one may expect that employed people may be more technology-literate. Two regressors were used: percentage of employed people over 15 years of age, and the same percentage for the age group 20 to 64 . The data for the first variable were obtained from World Bank Open Data, whilst those for the second variable were obtained from Eurostat Database Information Service.

The fourth group of variables was related to education, since one may expect that people who study for a longer period - for instance reaching tertiary level - may be more technology-conversant, and more prone to use novel payment instruments (in line with prior literature cited above). We thus considered the percentage of tertiary education enrolment, and tertiary educational attainment for the age group 30 to 34 . The data for the former variable were obtained from the Global Competitiveness Report 2016-2017, whilst those for the latter variable were obtained from Eurostat Database Information Service.

The fifth characteristic which was considered was technology. Countries adopting more upto-date technology may be expected to use recently-developed payment systems. Four different variables were chosen as proxies of technological progress: availability of latest technologies, government procurement of advanced technology products, financial market development and percentage of internet users. The data for these variables were obtained from the Global Competitiveness Report 2016-2017. In case of the first three variables, the yardsticks were compiled through executive opinion surveys where participants assigned a rating on a Likert scale.

The sixth characteristic which was considered was the openness of the economy, proxied by the imports of goods and services as a ratio of GDP. One may expect that a higher ratio of cross-border transactions may necessitate more efficient payment systems, leading to lower reliance on traditional payment methods. The imports data were obtained from World Bank Open Data.

As a rule, we avoided using related variables in the same model to minimise the potential for multicollinearity. We tested numerous specifications of the model, and explanatory variables were retained or omitted, depending on their statistical significance and overall explanatory power. The final version of the model (Table 2 Panel A) was selected on the basis of the statistical significance of the regressors, and highest explanatory power across the estimated models.

The most significant variable in the model was the percentage of the population aged between 20 and 39; however the sign was in the unexpected direction indicating that this relatively young age bracket is positively correlated with the reliance on traditional instruments. Having said this, the effect of demographics on payments systems use may be intricate, as suggested by the presence of an additional age-related variable in the model which is statistically significant and in the expected direction. (These trends are somewhat in line with the findings of Köse and Güleryüz (2020) that age has a non-linear relationship with internet banking adoption; in view of this conundrum, we devoted particular attention to this characteristic in our questionnaire design to counter-check its robustness). Financial market development and tertiary education attainment were also statistically significant and their direction was in line with expectations, indicating that these contribute to lower reliance on traditional payment instruments. The percentage of male population proved significant as well, suggesting that a higher proportion of males may be 
associated with lower reliance on traditional payment methods. Finally, government procurement of technology products is statistically significant but in the unexpected direction.

Table 2.Modelling the use of payment instruments across countries

\begin{tabular}{|c|c|c|c|c|}
\hline & \multicolumn{2}{|c|}{ Panel A: } & \multicolumn{2}{|c|}{ Panel B: } \\
\hline & Coefficient & t-ratio & Coefficient & t-ratio \\
\hline Population aged $20-39$ ( $\%$ of total) & 0.682 & $4.90 * * *$ & & \\
\hline Financial market development & -3.244 & $4.39 * * *$ & -1.360 & $2.18 * *$ \\
\hline Population aged $15-64$ ( $\%$ of total) & -1.014 & $3.47 * * *$ & & \\
\hline Gov't procurement of adv. tech. products & 2.691 & $2.92 * * *$ & & \\
\hline Tertiary educ. attainment, ages $30-34(\%)$ & -0.124 & $2.77 * * *$ & & \\
\hline Tertiary education enrolment rate (\%) & & & -0.065 & $2.39 * *$ \\
\hline Population, male ( $\%$ of total) & -0.646 & $2.11 * *$ & & \\
\hline Intercept & 75.475 & $3.16 * * *$ & 13.146 & $3.64 * * *$ \\
\hline R-Squared & \multicolumn{2}{|c|}{0.637} & \multicolumn{2}{|c|}{0.250} \\
\hline Adjusted R-Squared & \multicolumn{2}{|c|}{0.533} & \multicolumn{2}{|c|}{0.190} \\
\hline \multicolumn{5}{|c|}{$\begin{array}{l}\text { The model with the highest explanatory power is shown in Panel } A \text {, while a different } \\
\text { version which omits relationships which were not in line with expectations is shown in } \\
\text { Panel B. } \\
\text { T-ratios are reported next to the respective coefficients. } \\
\text { Statistical significance at the } 99 \% \text { and } 95 \% \text { levels of confidence is denoted by *** and ** } \\
\text { respectively. }\end{array}$} \\
\hline
\end{tabular}

Table 3. Consistency of the Explanatory Variables in the Series of Estimated Models

\begin{tabular}{lll}
\hline & Significance & Sign \\
\hline Population ages 20-39 (\% of total) & Consistently signif. & Consistently +ve \\
Population ages 15-64 (\% of total) & Mostly significant & Mostly -ve \\
Gov't procurement of adv. tech. products & Some significance & Consistently +ve \\
Population, male (\% of total) & Some significance & Consistently -ve \\
Financial market development & Some significance & Consistently -ve \\
Tertiary education enrolment rate & Some significance & Consistently -ve \\
Tertiary educational attainment, age: 30-34 & Some significance & Mostly -ve \\
Imports of goods and services (\% of GDP) & Consistently insign. & Mostly -ve \\
Employment rate, age group 20-64 & Consistently insign. & Mostly -ve \\
Employment to population ratio, 15+ & Consistently insign. & Consistently +ve \\
Availability of latest technologies & Consistently insign. & Mostly -ve \\
Internet users - \% pop. & Consistently insign. & Mostly +ve \\
\hline
\end{tabular}

Considering the series of estimated models, for each variable we summarise the consistency of statistical significance (second column) and the consistency of the sign (third column).

When we estimated further models and omitted those variables which proved significant in the unexpected direction, we got a noteworthy reduction in explanatory statistics. The model with the highest explanatory power from this second round of estimations is shown in Table 2 Panel B. 
The latter model confirms that financial market development and tertiary education contribute towards lower reliance on traditional payments systems.

As a form of robustness checking, in Table 3 we consider each sampled variable individually and summarise its consistency across the series of thirty one models which were estimated using this data set. The above insights are confirmed, in that the signs of most of the variables included in the former two models were in a consistent direction (although not necessarily in the expected direction). Not all variables included in the above two models were consistently significant across all estimations. This is due to the fact that when we estimated regressions which omitted the age variable that ran in the unexpected direction, we obtained an overall reduction in statistical significance.

\section{Questionnaire Findings}

In this section we present the main insights of a questionnaire held among 90 randomly-chosen respondents based in Malta. This exercise was conducted between January and March 2019 and printed copies were distributed to bank customers who were in the proximity of bank branches in Valletta. This offered the advantages associated with convenience sampling, and due to the choice of a central and busy location, respondents originated from different parts of the country and varied in terms of their demographic characteristics as shown in Table 4.

Table 4. Demographic Characteristics of the Respondents

\begin{tabular}{|c|c|c|c|c|c|c|}
\hline \multicolumn{7}{|l|}{ Gender: } \\
\hline Males & \multicolumn{6}{|l|}{ Females } \\
\hline $50 \%$ & \multicolumn{6}{|l|}{$50 \%$} \\
\hline \multicolumn{7}{|l|}{ Age: } \\
\hline $16-29$ years & $30-45$ years & $46-60$ years & & \multicolumn{3}{|c|}{ Over 60 years } \\
\hline $22 \%$ & $32 \%$ & $31 \%$ & & \multicolumn{3}{|l|}{$14 \%$} \\
\hline \multicolumn{7}{|l|}{ Education: } \\
\hline Primary & Secondary & Post-Secondary & & \multicolumn{3}{|l|}{ Tertiary } \\
\hline $2 \%$ & $30 \%$ & $26 \%$ & & \multicolumn{3}{|l|}{$42 \%$} \\
\hline \multicolumn{7}{|l|}{ Occupation: } \\
\hline Self-Employed & Employed & Unemployed & Student & & Retired & Other \\
\hline $9 \%$ & $70 \%$ & $3 \%$ & $4 \%$ & & $9 \%$ & $4 \%$ \\
\hline \multicolumn{7}{|l|}{ Locality: } \\
\hline Nothern Malta & Southern Malta & Gozo & & & & \\
\hline $51 \%$ & $43 \%$ & $6 \%$ & & & & \\
\hline
\end{tabular}

The table shows the composition of the questionnaire respondents in terms of gender, age, education, occupation and locality.

As shown in Appendix $B$, the questionnaire was divided in three sections, with each section serving a different purpose. Section $A$ of the questionnaire sought the information required to compile demographic and lifestyle characteristics of the participants, while Section B asked for information about the typical use of a variety of payment instruments. Section $C$ was intended to investigate the possible adoption of alternative payment methods.

Participants were first asked about the access and usage of a selection of payment instruments 
as shown in Table 5. With the exception of cash, we note that although respondents may have access to particular payment methods, they do not necessarily use them. On average, the likelihood of those respondents having access to a particular payment method to actually use that service is about $84 \%$. When analysing the use of payment instruments in terms of gender, we did not discern any substantial differences, however direct debits, credit cards, debit cards, and mobile banking were more likely to be used by males, whereas credit transfers, cheques and internet banking were more likely to be used by females. Similarly, when considering the use of payment instruments in terms of academic attainment (Table 6), we noted that people reaching tertiary education were the most prevalent to use each respective payment instrument except for credit cards and cheques which were mostly used by those attaining a post-secondary level of education. Respondents who only attained primary education do not use credit transfers, direct debits or mobile banking.

Table 5. Access and Use of Different Payment Instruments

\begin{tabular}{lccc}
\hline & Access & Use & Likelihood of Usage \\
\hline Cash & $100 \%$ & $100 \%$ & 1.00 \\
Debit cards & $94 \%$ & $90 \%$ & 0.96 \\
Internet banking & $86 \%$ & $74 \%$ & 0.86 \\
Direct debits & $81 \%$ & $57 \%$ & 0.70 \\
Cheques & $79 \%$ & $70 \%$ & 0.89 \\
Credit transfers & $77 \%$ & $61 \%$ & 0.79 \\
Credit cards & $66 \%$ & $50 \%$ & 0.76 \\
Mobile banking & $47 \%$ & $36 \%$ & 0.77 \\
Average & & & $\mathbf{0 . 8 4}$ \\
\hline
\end{tabular}

The table shows the percentages of the respondents who have access to the payment instrument (column 2) and the percentage who actually use the instrument (column 3). The third column shows the likelihood of use, in terms of the proportion of use: access (column 3 divided by column 2).

Considering the use of payment instruments across age categories (Table 7), all respondents aged between 16 to 29 and 30 to 45 use debit cards. Credit transfers, direct debits, credit cards, cheques and mobile banking, were mostly used by people within the age group from 30 to 45 . Internet banking was mostly used by the 16 to 29 age group. In case of the 46 to 60 age group, the mostly used payment instruments were cash and debit cards and the least used payment instrument was mobile banking. In case of respondents aged over 60, cash was the mostly used payment instrument whereas mobile banking was not used. This suggests that the choice of payment instruments may be sensitive to generational differences, as found in prior literature focusing on Maltese respondents (Camilleri and Grech, 2017).

In Table 8 the use of payment instruments is classified as per employment categories. We note that retired people predominantly use cash as a payment instrument, students make relatively less use of cheques and credit cards, while only a minority of unemployed persons use credit cards or mobile banking. 
Table 6. Use of Payment Instruments Classified by Academic Attainment

\begin{tabular}{lrrrr}
\hline & Primary & Secondary & Post-Secondary & Tertiary \\
\hline Cash & $100 \%$ & $100 \%$ & $100 \%$ & $100 \%$ \\
Debit card & $50 \%$ & $70 \%$ & $100 \%$ & $100 \%$ \\
Internet banking & $50 \%$ & $56 \%$ & $74 \%$ & $89 \%$ \\
Direct debit & $0 \%$ & $30 \%$ & $65 \%$ & $74 \%$ \\
Cheques & $50 \%$ & $63 \%$ & $78 \%$ & $71 \%$ \\
Credit transfer & $0 \%$ & $22 \%$ & $74 \%$ & $84 \%$ \\
Credit card & $50 \%$ & $33 \%$ & $61 \%$ & $55 \%$ \\
Mobile banking & $0 \%$ & $19 \%$ & $26 \%$ & $55 \%$ \\
\hline
\end{tabular}

The percentage of users from the respective academic attainment categories, is shown for each payment instrument.

Table 7. Use of Payment Instruments Classified by Age Brackets

\begin{tabular}{lrrrr}
\hline & $16-29$ & $30-45$ & $46-60$ & Over 60 \\
\hline Cash & $100 \%$ & $100 \%$ & $100 \%$ & $100 \%$ \\
Debit card & $100 \%$ & $100 \%$ & $89 \%$ & $54 \%$ \\
Internet banking & $95 \%$ & $86 \%$ & $64 \%$ & $38 \%$ \\
Direct debit & $55 \%$ & $72 \%$ & $64 \%$ & $8 \%$ \\
Cheques & $40 \%$ & $90 \%$ & $82 \%$ & $46 \%$ \\
Credit transfer & $75 \%$ & $79 \%$ & $54 \%$ & $15 \%$ \\
Credit card & $25 \%$ & $76 \%$ & $57 \%$ & $15 \%$ \\
Mobile banking & $50 \%$ & $55 \%$ & $21 \%$ & $0 \%$ \\
\hline
\end{tabular}

The percentage of users from the respective age categories, is shown for each payment instrument.

Participants were also asked about the frequency of use of the respective payment instruments and responses are summarised in Table 9. Overall it transpires that cash is the most frequently used payment method, followed by debit cards. Mobile banking, credit cards, and direct debits are the least frequently used. These preferences are in line with the responses obtained when participants were asked to select their preferred payment instrument (since there could be a difference between the preferred payment method and the one which is most frequently used). $49 \%$ of respondents selected cash and $44 \%$ selected debit cards. Credit cards were preferred by $3 \%$, followed by cheques $(1 \%)$ and internet banking $(1 \%)$. None of the participants opted for credit transfers or direct debits. Asked for the reasons why cash is used as a payment instrument, $78 \%$ of the participants indicated that it is more practical for small value transactions and $56 \%$ specified that cash may be used in much more contexts as compared to cards. The tendency for selecting cash for smaller-denomination transactions, is in line with the evidence presented by Wang and Wolman (2016) in the context of US-based retail data. As for bank payment cards, $66 \%$ of the respondents indicated that these are more practical for larger-denomination transactions and $50 \%$ specified that they are easy and convenient to use. This suggests that the respondents opt to use cash and bank cards (rather than more recent payment systems) since they find them convenient to use - rather than due to a specific aversion to new technologies. 
Table 8. Use of Payment Instruments Classified by Employment Categories

\begin{tabular}{lrrrrrr}
\hline & Self-Employed & Employed & Unemployed & Student & Retired & Other \\
\hline Cash & $100 \%$ & $100 \%$ & $100 \%$ & $100 \%$ & $100 \%$ & $100 \%$ \\
Debit card & $100 \%$ & $98 \%$ & $67 \%$ & $100 \%$ & $38 \%$ & $50 \%$ \\
Internet bkg. & $100 \%$ & $79 \%$ & $100 \%$ & $75 \%$ & $13 \%$ & $50 \%$ \\
Direct debit & $75 \%$ & $60 \%$ & $67 \%$ & $75 \%$ & $0 \%$ & $50 \%$ \\
Cheques & $100 \%$ & $73 \%$ & $100 \%$ & $0 \%$ & $38 \%$ & $75 \%$ \\
Credit transfer & $88 \%$ & $65 \%$ & $100 \%$ & $75 \%$ & $0 \%$ & $25 \%$ \\
Credit card & $50 \%$ & $59 \%$ & $33 \%$ & $25 \%$ & $13 \%$ & $25 \%$ \\
Mobile banking & $50 \%$ & $38 \%$ & $33 \%$ & $50 \%$ & $0 \%$ & $25 \%$ \\
\hline
\end{tabular}

The percentage of users from the respective employment categories, is shown for each payment instrument.

The questionnaire also aimed at obtaining an insight about the respondents' likelihood to use more recent payment instruments. $82 \%$ of the participants were aware that mobile phones may be used for payment purposes; and age-related differences were evident in this respect. All participants aged below 29 were familiar with this facility but over half of the respondents aged over 60 were unaware of it. $54 \%$ of the respondents also answered that they would consider using mobile phones as a payment channel. The majority of respondents aged 16-29 and 30-45 would consider using such facility whereas the majority of respondents over 46 years of age did not intend to use it. The most commonly cited reasons why respondents would not consider using mobile phones for payment purposes were security concerns and the possibility of becoming more liberal with spending habits. Participants also indicated that further awareness about alternative payment instruments and additional benefits when using internet or cards-based systems would encourage them to use such methods. Notwithstanding this, questionnaire results which rely on responses about the foreseen future use of payment instruments should be interpreted with caution since it could be the case that respondents show willingness to adopt new payment methods however few of them actually do so in practice (Harasim and Klimontowicz, 2013).

Table 9. Frequency of Use for Each Payment Instrument

\begin{tabular}{lrrrrr}
\hline & Very Frequent & Frequently & Sometimes & Rarely & Never \\
\hline Cash & $76 \%$ & $17 \%$ & $5 \%$ & $2 \%$ & $0 \%$ \\
Debit card & $49 \%$ & $20 \%$ & $17 \%$ & $4 \%$ & $10 \%$ \\
Internet banking & $28 \%$ & $26 \%$ & $17 \%$ & $5 \%$ & $24 \%$ \\
Direct debit & $7 \%$ & $18 \%$ & $26 \%$ & $11 \%$ & $38 \%$ \\
Cheques & $4 \%$ & $17 \%$ & $34 \%$ & $17 \%$ & $28 \%$ \\
Credit transfer & $7 \%$ & $23 \%$ & $26 \%$ & $12 \%$ & $32 \%$ \\
Credit card & $11 \%$ & $16 \%$ & $13 \%$ & $12 \%$ & $48 \%$ \\
Mobile banking & $16 \%$ & $9 \%$ & $8 \%$ & $3 \%$ & $64 \%$ \\
\hline
\end{tabular}

The table shows the frequency of use of the respective payment instruments, as indicated by the questionnaire respondents.

Overall, the questionnaire suggests that despite the wider choices of payment methods, cash is mostly preferred and debit cards rank thereafter. Indeed, when asked whether they would consider giving up cash in favour of other payment instruments, only $23 \%$ of the participants indicated 
that they would be willing to do so. One factor which should be considered in this respect is that cash offers reasonable confidentiality, where the particulars of the underlying transaction are only known to the payer and the payee. This does not usually apply to technology-based payments.

\section{Discussion}

Whilst the former econometric models and questionnaire were so far presented as distinct elements, in this section we offer some further discussion to consider the main insights of the respective approaches in a joint manner.

We note how particular factors emerged as highly relevant in explaining the transition towards more innovative payment systems, across both empirical tasks. This is even more noteworthy when considering that one may expect some degree of incongruence owing to the contrasts in between the empirical investigations. As previously stated, whereas the questionnaire was mainly conducted amongst retail bank customers, the data which were used for the econometric models also comprise business-related factors, such as yardsticks relating to technology and employment. In addition, whereas the econometric model captures a sample of European countries, the questionnaire exclusively reflects the trends pertaining to a single country which may differ from the rest (Dahlberg et al., 2008). Another subtle variation lies in the fact that most of the data used in the econometric model were denominated in currency, whereas the data collected through the questionnaire relate mostly to the frequency of using particular payment methods. This implies that in the former data set, larger payments attain a greater weighting than smaller payments, whereas this is not the case with the latter data set.

One factor which emerged as particularly important in explaining the tendency to adopt relatively new payment instruments as opposed to relying on traditional ones is generational differences. Indeed in the econometric model it emerged that the percentage of the population within the age bracket 15-64 is negatively related to the reliance on traditional payment channels (suggesting that people aged over 64 tend to rely more on traditional payment mechanisms). This was confirmed by the questionnaire finding that respondents aged over 60 , mostly used cash as a payment instrument and that they do not use mobile banking. Having said this, as per the econometric findings, people aged between 20 and 39 may be positively associated with the reliance on traditional payment instruments - which is in the unexpected direction. This may suggest that while there are substantial differences in payment preferences in case of over-60s, any generational differences applicable to the relatively younger bracket are not leading to significantly higher use of more innovative payment methods.

Educational attainment also emerged as an important aspect. Variables related to tertiary education proved significant in terms of reducing the tendency to rely on traditional payment methods in the econometric models. In the questionnaire it emerged that people reaching tertiary education are most prevalent to use a variety of payment instruments (except for credit cards and cheques) while respondents who only attained primary education do not use credit transfers, direct debits or mobile banking.

Referring to gender differences, these definitely do not rank commensurately with the former two factors in terms of explaining the tendency to rely on traditional payment methods. However, one may speak of some statistical significance in the econometric models, and some differences in the prevalent types of instruments used by males and females as suggested by the questionnaire responses.

In the econometric model, it also emerged that financial market development overall reduces the tendency to use traditional payment instruments, although this aspect was not tackled in the 
questionnaire since the latter mainly focused on characteristics at the individual level.

\section{Conclusion}

Payment instruments are essential in the settlement of transactions and in this way their efficiency is vital for economies to remain at the forefront of economic development. Recent technological advances permitted a variety of novel payment systems which are often quicker and offer reasonable security. The adoption and usage trends of payment instruments are expected to remain at the forefront on the agendas of private firms, academics, and policy makers as new advances such as blockchain present the potential of even more innovative facilities, which impact on business efficiency, financial inclusion and regulatory efforts (Mills et al., 2018; Handayani et al., 2020). Businesses and individuals may vary in terms of their likelihood to use new payment systems, given that people may at times postpone the adoption of innovative payment methods due to lack of awareness and inertia. Given this, an understanding of the factors which dissuade or encourage the adoption of new payment systems is of paramount importance.

In this paper, our main aim was to explore how the transition in the use of salient payment systems is related to socio-economic factors. We first estimated cross-country regressions to model the degree of reliance on traditional payment systems and then conducted a questionnaire featuring respondents based in Malta to obtain an understanding of payment habits at the individual level. The contributions of our study are twofold: firstly we did not limit ourselves to focus on the adoption of one particular payment method, but rather modelled the general reliance on relatively traditional payment systems as compared to newer instruments. In this way we expect our insights to remain relevant when analysing salient trends in the near future, at which point payments systems would have evolved even further. Our second important contribution is that our complementary empirical approaches are likely to encompass both wholesale payment trends as shaped by businesses and retail payment attitudes at the individual level.

The econometric models suggest that financial market development and the diffusion of tertiary education are negatively related to the use of traditional payment instruments and this is in line with expectations. Age-related variables yielded mixed insights; the proportion of population aged between 20 and 39 was positively related to the reliance on traditional payment systems (contrary to expectations) whereas the proportion of the population aged between 15 and 64 was negatively related to the use of traditional payment methods.

In the questionnaire we noted that the likelihood of respondents to actually use the payment methods which they have access to, stands at about $84 \%$. People reaching tertiary education are most prevalent to use each respective payment instrument except for credit cards and cheques which are mostly used by those attaining a post-secondary level of education. Respondents who only attained primary education do not use credit transfers, direct debits or mobile banking.

We noted salient differences when considering the use of payment instruments across age categories; for instance internet banking was mostly used by the 16 to 29 age group whereas respondents aged over 60 mostly use cash and do not use mobile banking. Cash is used by all respondents irrespective of age categories, but it is the predominant payment method for over sixties. Differences across age groups also emerged when considering the awareness about novel facilities such as mobile phone payments and the possible future adoption. The notion that the choice of retail payment instruments may be sensitive to generational differences is in line with prior literature focusing on Maltese respondents (Camilleri and Grech, 2017).

Participants overall indicated that their preference for cash is based on the fact that it is more practical for small value transactions and may be used in more contexts as compared to 
cards. The next ranking popular payment instrument were debit cards which seem preferred for higher-value purchases, online shopping, and when a record of payment is to be retained. This suggests that respondents use cash and bank cards because they find them convenient rather than due to an aversion to novel payment systems or technologies. This is in line with the study by Saliba and Muscat (2020) where Maltese households indicated that their use of particular payment instruments was due to the ease of use and promptness. In addition, it seems to differ from the insights obtained by Camilleri et al. (2013) focusing on Maltese respondents, which suggest that people refrained from using services such as internet banking due to unfamiliarity and lack of confidence. The observation that cash and debit cards are the most frequently used payment instruments in Malta, is in line with the results of Saliba and Muscat (2020) where the proportion of households which confirmed that they do not use such instruments stood at around $2 \%$ and $31 \%$ respectively. This evidence is also corroborated by European trends, whereby Esselink and Hernàndez (2017) reported that as at 2016, 79\% of retail sales payments were made in cash, representing $54 \%$ in terms of value. In our study, when respondents were asked whether they would consider giving up cash in favour of other payment instruments, only $23 \%$ of the participants indicated that they would be willing to do so.

This study has important implications both in terms of contributing to the broader body of academic literature as well as from a practical point of view. In particular, our focus on the relationship between the reliance on relatively traditional payment systems and socio-economic characteristics across countries contributes towards addressing the shortage of literature about how payments systems may be influenced by the social and cultural environment - a research lacuna discussed by Dahlberg et al. (2008). From a business-oriented viewpoint, our results contribute towards a more coherent understanding of the factors that shape the tendencies towards the adoption of novel payment systems. Such aspects are vital from the point of view of businesses who may face increased demands (or inertia) for the settlement of transactions through newly-developed payments systems, and they are also relevant to financial institutions due to the likely impacts on their traditional income stream of the provision of payment services.

Our conclusions should be interpreted in the context of the limitations of the research process. In particular, the likelihood of adopting innovative payment systems may be influenced by factors which we did not consider in our analysis. In order to minimise this possibility, we started with a considerable diversity of explanatory variables and omitted different ones successively when they proved insignificant in the econometric models. Similarly, the administration of questionnaires is liable to shortcomings for instance if respondents are not completely honest in their answers or when questions are not suitably understood. Given this, we offered respondents any required assistance when this was requested. Finally, given that payment habits are likely to differ across countries (Dahlberg et al., 2008), the insights attained from the questionnaire conducted amongst Maltese respondents may not necessarily be generalisable across a wider range of countries.

In view of the insights obtained in this study and the limited volume of research about the adoption of different payment systems, we may suggest different issues for possible future research. Additional investigation may be directed at assessing our empirical result that one of the age-related variables ran counter to original expectations. A further salient issue is how the tendency to rely on relatively traditional payment instruments may impact on general economic development and competitiveness. 


\section{References}

Abrahão, R., Moriguchi, S., \& Andrade, D. (2016). Intention of adoption of mobile payment: an analysis in the light of the unified theory of acceptance and use of technology (UTAUT). RAI Revista de Administração e Inovação, 13, 221-230.

Abu-Assi, H., Al-Dmour, H., \& Al-Zu'bi, Z. (2014). Determinants of internet banking adoption in Jordan. International Journal of Business and Management, 9(12), 169-196.

Aigbe, P., \& Akpojaro, J. (2014). Analysis of security issues in electronic payment systems. International Journal of Computer Applications, 108(10), 10-14.

Alalwan, A., Dwivedi, Y., \& Rana, N. (2017). Factors influencing adoption of mobile banking by Jordanian bank customers: Extending UTAUT2 with trust. International Journal of Information Management, 37(3), 99-110.

Alalwan, A., Dwivedi, Y., Rana, N., \& Algharabat, R. (2018). Examining factors influencing Jordanian customers' intentions and adoption of internet banking: Extending UTAUT2 with risk. Journal of Retailing and Consumer Services, 40, 125-138.

Al-Hujran, O., Al-Debei, M., Chatfield, A., \& Migdadi, M. (2015). The imperative of influencing citizen attitude toward e-government adoption and use. Computers in Human Behavior, 53, 189-203.

Al-Tarawneh, J.M. (2016). Factors influencing the adoption of Mobile banking services in Jordan from the perspective of customers: Overview and Pilot study. International Journal of Scientific and Research Publications, 6(9), 207-221.

Apanasevic, T., Arvidsson, N., \& Markendahl, J. (2018). Mobile payments: a proposal for a context-oriented approach based on socio-technical system theory. Journal of Innovation Management, 6(3), 40-97.

Arango, C., Hogg, D., \& Lee, A. (2012). Why is cash (still) so entrenched? insights from the Bank of Canada's 2009 methods-of-payment survey, Discussion Paper, Bank of Canada, 2012-2.

Barber, B.M., \& Odean, T. (2001). Boys will be boys: gender, overconfidence, and common stock investment. The Quarterly Journal of Economics, 116(1), 261-292.

Bar-Gill, O. (2004). Seduction by plastic. Northwestern University Law Review, 98, 1373-1434.

Bengtsson, C., Persson, M., \& Willenhag, P. (2005). Gender and overconfidence. Economics Letters, 86(2), 199-203.

Black, N. J., Lockett, A., Ennew, C., Winkihofer, H., \& McKechnie, S. (2002). Modelling consumer choice of distribution channels: an illustration from financial services. International Journal of Bank Marketing, 20(4), 161-173.

Borzekowski, R., Kiser, E., \& Ahmed, S. (2008). Consumers' use of debit cards: patterns, preferences, and price response. Journal of Money Credit and Banking, 40(1), 149-172.

Buszko, M., Krupa, D., \& Chojnacka, M. (2019). Young people and banking products and services in Poland: the results of empirical studies. Ekonomia i Prawo. Economics and Law, 18(2), 147-164. doi:10.12775/EiP.2019.012.

Camilleri, S.J. (2006). International Financial Markets. In A.K. Vaidya (ed.) Globalization: Encyclopedia of Trade, Labor, and Politics, (pp. 130-138). ABC-CLIO Publishers, Santa Barbara, 
California.

Camilleri, S.J., \& Ellul, D. (2017). Younger customers' outlooks when selecting and changing a financial services provider: the case of Maltese students. International Journal of Financial Research, 8(2), 51-63.

Camilleri, S.J., \& Grech, G. (2017). The relevance of age categories in explaining internet banking adoption rates and customers' attitudes towards the service. Journal of Applied Finance and Banking, 7(2), 29-47.

Camilleri, S.J., Cortis, J., \& Fenech, M.D. (2013). Service quality and internet banking: perceptions of Maltese retail bank customers. Bank of Valletta Review, 48(2), 1-17. Retrieved from: https://www.um.edu.mt/library/oar/handle/123456789/34893? mode=full.

Carow, K.A., \& Staten, M. (1999). Debit, credit, and cash: survey evidence on gasoline purchases. Retrieved from: Journal of Economics and Business, 51(5), 409-422.

Chakravorti, S. (2003). Theory of credit card networks: a survey of literature. Review of Network Economics, 2(2), 50-68.

Chi, S.Y., Grant, K., \& Edgar, D. (2007). Factors affecting the adoption of internet banking in Hong Kong-implications for the banking sector. International Journal of Information Management, 27(5), 336-351. Retrieved from: http://dx.doi.org/10.1016/j.ijinfomgt.2007.03.002.

Cho, Y. (2008). Assessing user attitudes toward mobile commerce in the U.S. vs. Korea: Implications for m-commerce CRM. The Journal of Business and Economics Research, 6(2), 91-102.

Chong, A., Ooi, K.B., Lin, B., \& Tan, B.I. (2010). Online banking adoption: an empirical analysis. International Journal of Bank Marketing, 28(4), 267-287.

Chung, J. E., Stoel, L., Xu, Y., \& Ren, J. (2012). Predicting Chinese consumers' purchase intentions for imported soy-based dietary supplements. British Food Journal, 114(1), 143-161.

Dahlberg, T., Mallat, N., Ondrus, J., \& Zmijewska, A. (2008). Past, present and future of mobile payments research: A literature review. Electronic Commerce Research and Applications, 7(2), $165-181$.

Davis, F.D. (1989). Perceived usefulness, perceived ease of use, and user acceptance of information technology. MIS Quarterly, 13(3), 319-340.

Dennehy, D., \& Sammon, D. (2015). Trends in mobile payments research: A literature review. Journal of Innovation Management, 3(1), 49-61.

Eriksson, K., Kerem, K., \& Nilsson, D. (2005). Customer acceptance of Internet banking in Estonia. International Journal of Bank Marketing, 23(2), 200-216. Retrieved from: http: //dx.doi.org/10.1108/02652320510584412.

Esselink, H., \& Hernández, L. (2017). The use of cash by households in the euro area. ECB Occasional Paper, No. 201, ISBN 978-92-899-2863-2, European Central Bank (ECB), Frankfurt. Retrieved from: http://dx.doi.org/10.2866/377081.

Frame, S.W., \& White, L.J. (2004). Empirical studies of financial innovation: lots of talk, little action? Journal of Economic Literature, 42(1), 116-144.

Gefen, D., \& Straub, D.W. (1997). Gender differences in the perception and use of e-mail: an extension to the technology acceptance model. MIS Quarterly, 21(4), 389-99. 
George, A. (2018). Perceptions of internet banking users - a structural equation modelling approach. IIMB Management Review, 30(4), 357-368.

González, A.G. (2004). PayPal: the legal status of C2C payment systems. Computer Law and Security Report, 20(4), 293-299.

Gounaris, S., \& Koritos, C. (2008). Investigating the drivers of internet banking adoption decision. International Journal of Bank Marketing, 26(5), 282-304. Retrieved from: http: //dx.doi.org/10.1108/02652320810894370.

Guibourg, G., \& Segendorff, B. (2007). A note on the price- and cost structure of retail payment services in the Swedish banking sector 2002. Journal of Banking and Finance, 31(9), 2817-2827.

Handayani, S., Martini, A., \& Thomson, E. (2020). Is Libra_Facebook's new currency can increase financial inclusiveness? In 3rd International Research Conference on Economics and Business, KnE Social Sciences, pp. 414-423. DOI 10.18502/kss.v4i7.6871.

Harasim, J., \& Klimontowicz, M. (2013). Payment habits as a determinant of retail payment innovations diffusion: the case of Poland. Journal of Innovation Management, 1(2), 86-102.

Harris, H., Guru, B.K., \& Avvari, M.V. (2011). Evidence of firms' perceptions toward electronic payment systems (EPS) in Malaysia. International Journal of Business and Information, 6(2), 226-245.

Hasan, I., De Renzis, T., \& Schmiedel, H. (2012). Retail payments and economic growth. Bank of Finland Research Discussion Papers 19. 2012.

Hayashi, F., \& Keeton, W.R. (2012). Measuring the costs of retail payment methods. Economic Review - Federal Reserve Bank of Kansas City, Fourth Quarter, 79-115.

Heng, S. (2007). E-commerce settles for established payment systems: Limited market potential for innovative payment systems. E-conomics, Deutsche Bank Research, 66, May 14.

Ho, S., \& Ng, V. (1994). Customers' risk perceptions of electronic payment systems. International Journal of Bank Marketing, 12(8), 26-38.

Huam, H. T., Khalil, M. N., Eng, T. Y., Khor, J. H., Lim, Y. M., \& Tan, L. Y. (2008). Predictors of intention to continue using internet banking services: an empirical study of current users. International Journal of Business and Information, 3(2), 233-244.

Humphrey, D., Kim, M., \& Vale, B. (2001). Realizing the gains from electronic payments: costs, pricing, and payment choice. Journal of Money, Credit, and Banking, 33(2), 216-234.

Humphrey, D., Willesson, M., Lindblom, T., \& Bergendahl, G. (2003). What does it cost to make a payment? The Review of Network Economics, 2(2), 159-174.

Humphrey, D.B. (2004). Replacement of cash by cards in U.S. consumer payments. Journal of Economics and Business, 56(3), 211-225.

Hwang, R., Shiau, S., \& Jan, D. (2007). A new mobile payment scheme for roaming services. Electronic Commerce Research and Applications, 6(2), 184-191.

Jayawardhena, C., \& Foley, P. (2000). Changes in the banking sector - the case of Internet banking in the UK. Internet Research: Electronic Network Applications and Policy, 10(1), 19-31.

Jonker, N. (2005). Payment instruments as perceived by consumers - a public survey, Working paper, De Nederlandsche Bank, DNB Working Papers 053. 
Karjaluoto, H., Mattila, M., \& Pento, T. (2002). Factors underlying attitude formation toward online banking in Finland. International Journal of Bank Marketing, 20(6), 261-272. Retrieved from: http://dx.doi.org/10.1108/02652320210446724.

Khalilzadeh, J., Ozturk, A., \& Bilgihan, A. (2017). Security-related factors in extended UTAUT model for NFC based mobile payment in the restaurant industry. Computers in Human Behavior, $70,460-474$.

Khan, B., Olanrewaju, R., Baba, A., Langoo, A., \& Assad, S. (2017). A compendious study of online payment systems: past developments, present impact, and future considerations. International Journal of Advanced Computer Science and Applications, 8(5), 256-271.

Kim, C., Mirusmonov, M., \& Lee, I. (2010b). An empirical examination of factors influencing the intention to use mobile payment. Computers in Human Behavior, 26(3), 310-322.

Kim, C., Tao, W., Shin, N., \& Kim, K. (2010a). An empirical study of customers' perceptions of security and trust in e-payment systems. Electronic Commerce Research and Applications, 9(1), 84-95.

Koenig-Lewis, N., Morgan, M., Palmer, A., \& Zhao, A. (2015). Enjoyment and social influence: predicting mobile payment adoption. The Service Industries Journal, 35(10), 537-554.

Köse, T., \& Güleryüz, E.H. (2020). Determinants of internet banking adoption in Turkey. Journal of Yasar University, 15(58), 167-176.

Kousaridas, A., Parissis, G., \& Apostolopoulos, T. (2008). An open financial services architecture based on the use of intelligent mobile devices. Electronic Commerce Research and Applications, $7(2), 232-246$.

Laforet, S., \& Li, X. (2005). Consumers' attitudes towards online and mobile banking in China. International Journal of Bank Marketing, 23(5), 362-380.

Laukkanen, T., \& Lauronen, J. (2005). Consumer value creation in mobile banking services. International Journal of Mobile Communications, 3(4), 325-338.

Lederer, A.L., Maupin, D.J., Sena, M.P., \& Zhuang, Y. (2000). The technology acceptance model and the world wide web. Decision Support System, 29(3), 269-282. Retrieved from: http://dx.doi.org/10.1016/S0167-9236(00)00076-2.

Lee, E., \& Lee, J. (2000). Haven't adopted electronic financial services yet? The acceptance and diffusion of electronic banking technologies. Financial Counseling and Planning, 111, 49-60.

Levitin, A.J. (2007). Payment wars: the merchant-bank struggle for control of payment systems. Stanford Journal of Law, Business and Finance, 12(2), 1-66.

Liébana-Cabanillas, F., Sánchez-Fernández, J., \& Muñoz-Leiva, F. (2014a). Role of gender on acceptance of mobile payment. Industrial Management and Data Systems, 1142, 220-240.

Liébana-Cabanillas, F., Sánchez-Fernández, J., \& Muñoz-Leiva, F. (2014b). Antecedents of the adoption of the new mobile payment systems: The moderating effect of age. Computers in Human Behavior, 35, 464-478.

Lu, Y., Yang, S., Chau, P., \& Cao, Y. (2011). Dynamics between the trust transfer process and intention to use mobile payment services: A cross-environment perspective. Information and Management, 48(8), 393-403.

Mallat, N. (2007). Exploring consumer adoption of mobile payments - A qualitative study. The 
Journal of Strategic Information Systems, 16(4), 413-432.

Maqableh, M., Masa'deh, R., Shannak, R., \& Nahar, K. (2015). Perceived trust and payment methods: an empirical study of markavip company. International Journal of Communications, Network and System Sciences, 8(11), 409-427.

Mehrad, D., \& Mohammadi, S. (2017). Word of Mouth impact on the adoption of mobile banking in Iran. Telematics and Informatics, 34(7), 1351-1363. https://doi.org/10.1016/j.tele.2016.08.009.

Mills, D., Wang, K., Malone, B., Ravi, A., Marquardt, J., Chen, C., Badev,A., Brezinski, T., Fahy, L., Liao, K., Kargenian, V., Ellithorpe, M., Ng, W., \& Baird, M. (2018). Distributed ledger technology in payments, clearing, and settlement. NMIMS Management Review, 36(2), 60-89.

Mirza, A.P., Wallstrom, A., \& Mirza, O.P. (2009). Adoption of internet banking by Iranian consumers: An empirical investigation. Journal of Applied Sciences, 9(4), 2567-2575.

Musa, A., Khan, H.U., \& AIShare, K.A. (2015). Factors influence consumers' adoption of mobile payment devices in Qatar. International Journal of Mobile Communications, 13(6), 670-689.

OECD. (2006). Online Payment Systems for E-commerce, OECD Digital Economy Papers, No. 117, OECD publishing, Paris. Retrieved from: https://doi.org/10.1787/231454241135.

Oliveira, T., Faria, M., Thomas, M., \& Popovic, A. (2014). Extending the understanding of mobile banking adoption: When UTAUT meets TTF and ITM. International Journal of Information Management, 34(5), 689-703.

Paunov, C., \& Vickery, G. (2006). Online payment systems for e-commerce. OECD Digital Economy Papers, No. 117, OECD publishing, Paris. https://doi.org/10.1787/231454241135.

Polatoglu, V. N., \& Ekin, S. (2001). An empirical investigation of the Turkish consumer's acceptance of internet banking services. International Journal of Bank Marketing, 19(4), 156 -165.

Pope, M., Pantages, R., Enachescu, N., Dinshaw, R., Joshlin, C., Stone, R., Austria, P. A., \& Seal. K. (2011). Mobile payments: The reality on the ground of United States and selected Asian countries. International Journal of Mobile Marketing, 6(2), 88-104.

Porter, C.E. (2001). What's in it for me? A consumer perspective on the causes and impacts of the digital divide. American Marketing Association: Marketing and Public Policy Conference Proceedings, 11, 68-9.

Riquelme, H.E., \& Rios, R.E. (2010). The moderating effect of gender in the adoption of mobile banking. The International Journal of Bank Marketing, 28(5), 328-341.

Rivera, J.W. (2019). Potential negative effects of a cashless society: Turning citizens into criminals and other economic dangers. Journal of Money Laundering Control, 222, 350-358.

Rogers, E.M. (1983). Diffusion of Innovations, Free Press, New York, NY.

Saliba, C., \& Muscat, M.A. (2020). Analysis of the payment habits in Malta. Research Paper Central Bank of Malta.

Shampine, A. (2007). Another look at payment instrument economics. Review of Network Economics, 6(4), 495-508.

Shergill, G. S., \& Li, B. (2005). Internet banking-an empirical investigation of customers' behaviour for online banking in New Zealand. Journal of E-Business, 5(1), 1-17.

Shin, S., Lee, W., \& Odom, D. (2014). A comparative study of smartphone user's perception 
and preference towards mobile payment methods in the U.S. and Korea. The Journal of Applied Business Research, 30(5), 1365-1376.

Siau, K., Sheng, H., Nah, F., \& Davis, S. (2004). A qualitative investigation on consumer trust in mobile commerce. International Journal of Electronic Business, 2(3), 283-300.

Slade, E.L., Dwivedi, Y.K., Piercy, N.C., \& Williams, M.D. (2015). Modeling consumers' adoption intentions of remote mobile payments in the United Kingdom: Extending UTAUT with Innovativeness, Risk, and Trust. Psychology and Marketing, 32(8), 860-873.

Sorkin, D.E. (2002). Payment methods for consumer-to-consumer online transactions. Akron Law Review, 35(1), Article 1.

Stewart, K., \& Segars, A. (2002). An empirical examination of the concern for information privacy instrument. Information Systems Research, 13(1), 36-49.

Stone, R.N., \& Gronhaug, K. (1993). Perceived risk: further considerations for the marketing discipline. European Journal of Marketing, 27(3), 39-50.

Suh, B., \& Han, I. (2003). The impact of customer trust and perception of security control on the acceptance of electronic commerce. Informational Journal of Electronic Commerce, 7(3), 135-161.

Sumanjeet, S. (2009). Emergence of payment systems in the age of electronic commerce: The state of art. Global Journal of International Business Research, 2(2), 17-36.

Telyukova, I., \& Wright, R. (2008). A model of money and credit with application to the credit card debt puzzle. The Review of Economic Studies, 75(2), 629-647.

ten Raa, T., \& Shestalova, V. (2004). Empirical evidence on payment media costs and switch points. Journal of Banking and Finance, 28(1), 203-213.

Teoh, W., Chong, S., Lin, B., \& Chua, J. (2013). Factors affecting consumers' perception of electronic payment: an empirical analysis. Internet Research, 23(4), 465-485. http://dx.doi.org/ 10.1108/IntR-09-2012-0199.

Trocchia, P.J., \& Janda, S. (2000). A phenomenological investigation of internet usage among older individuals. Journal of Consumer Marketing, 17(7), 605-616.

Tsiakis, T., \& Sthephanides, G. (2005). The concept of security and trust in electronic payments. Computers and Security, 24(1), 10-15.

Venkatesh, A., \& Morris, M.G. (2000). Why don't men ever stop to ask for directions? gender, social influence, and their role in technology acceptance and usage behavior. MIS Quarterly, 24(1), 115-39.

Waite, K., \& Harrison, T. (2004). Online banking information: what we want and what we get. Qualitative Market Research, 71, 67-79. https://doi.org/10.1108/13522750410512895.

Wang, Z., \& Wolman, A. (2016). Payment choice and currency use: Insights from two billion retail transactions. Journal of Monetary Economics, 84, 94-115.

Wessels, L., \& Drennan, J. (2010). An investigation of consumer acceptance of m-banking, International Journal of Bank Marketing, 28(7), 547-568.

World Economic Forum. (2013). Engaging tomorrow's consumer, A report by the World Economic Forum's Sustainable Consumption Initiative prepared in collaboration with Accenture. Retrieved from: http://www3.weforum.org/docs/WEF_RC_EngagingTomorrowsConsumer_Report_2013. 
pdf.

Yang, S., Lu, Y., Gupta, S., Cao, Y., \& Zhang, R. (2012). Mobile payment services adoption across time: An empirical study of the effects of behavioral beliefs, social influences, and personal traits. Computers in Human Behavior, 28(1), 129-142.

Zarmpou, T., Saprikis, V., Markos, A., \& Vlachopoulou, M. (2012). Modeling users' acceptance of mobile services. Electronic Commerce Research, 12(2), 225-248.

Zeithaml, V.A., \& Gilly, M.C. (1987). Characteristics affecting the acceptance of retailing technologies: a comparison of elderly and non-elderly consumers. Journal of Retailing, 63(1), 49-68.

Zhang, L., Zhu, J., \& Liu, Q. (2012). A meta-analysis of mobile commerce adoption and the moderating effect of culture. Computers in Human Behavior, 28(5), 1902-1911.

Zhou, T. (2013). An empirical examination of continuance intention of mobile payment services. Decision Support Systems, 54(2), 1085-1091.

Zhu, C., \& Fu, Z. (2020). Research on the development trend of traditional financial industry based on blockchain technology. Asian Journal of Research in Computer Science, 5(3), 1-6.

Zinman, J. (2007). Household borrowing high and lending low under no arbitrage. Working Paper, Hanover, NH: Dartmouth College.

Zinman, J. (2009). Debit or credit? Journal of Banking and Finance, 33(2), 358-366.

\section{Appendix A: Compiling an indicator of the reliance on traditional payment meth- ods.}

Our econometric model featured an indicator of the reliance on traditional payments systems as dependent variable. We did not limit this indicator to one type of instrument but rather included proxies for two traditional means of payments (cheques and ATMs), as opposed to the more recent tendencies for online / mobile payments.

The data used for compiling the indicator were as follows:

- Cheques as a percentage of the total number of payments for 2017 (sourced from the EU Central Bank Database)

- The percentage change in the number of ATMS provided by resident payment service providers for 2017 (sourced from the EU Central Bank Database); given that the 2017 figure for Latvia was not available, we took an average of the figures for 2016 and 2018 to fill in this missing observation.

- The percentage of people aged over fifteen, who made payments via mobile phone or internet for 2017 (sourced from the World Bank - G20 Financial Inclusion Indicators Database). This was used to factor in an element of more recent payments systems in our indicator.

The data were transformed as specified underneath in order to combine them in one single variable.

- In order to obtain a consistent indicator (where a higher value for each component denotes a higher reliance on traditional payment methods), the percentage of people who used mobile / internet payments was subtracted from $100 \%$, to obtain the percentage who did not use such payments. 
- Another transformation was required for the percentage increase / decrease in ATMS. In this case the original data ranged from $-12 \%$ (Belgium) to $+8.8 \%$ (Croatia). In select cases where there was a substantial downward change, this would have resulted in a negative overall indicator if these data were used in their original format. We thought that it was important to avoid a mixture of positive and negative observations in the final indicator since these would influence the overall direction of the regression coefficients in an inconsistent way across countries. Therefore the ATMs data were transposed by adding $12 \%$ to each observation to avoid negative numbers (changing the range to $0 \%-20.8 \%$ ).

In order to assign equal weightings to these three components, we did not simply add the respective original observations for each country, but rather scaled the numbers as per the overall average of each series. [The average for the cheques data was 1.73; therefore each observation in this series was divided by this number. Similarly transposed ATM observations were divided by 11.51 and the percentage of people not using mobile or online payments was divided by 53.42]. The scaled observations were then added together to compile a value for each country which denotes the reliance on traditional payment methods.

\section{Appendix B: Questionnaire}

\section{Section A - Demographics}

1. Gender (tick one)

$\square$ Male

$\square$ Female

2. Age (tick one)

ㅁ $16-29$

ㄴ $46-60$

ㅁ $30-45$

$\square$ Over 60 years

3. Education (tick one)

$\square$ Primary

$\square$ Secondary

$\square$ Post-Secondary Level

$\square$ Tertiary

4. Occupation (tick one)

$\square$ Self-Employed 

$\square$ Employed
$\square$ Unemployed
$\square$ Student
$\square$ Retired
$\square$ Other

5. Locality (tick one)

$\square$ Nothern Malta $\square$ Southern Malta $\square$ Gozo

\section{Section B - Current use of Payment Instruments}

6. Which of the following payment instruments do you have access to and make use of?

\begin{tabular}{|l|l|l|l|l|}
\hline & \multicolumn{2}{|c|}{$\begin{array}{c}\text { Do you have access } \\
\text { to this method? }\end{array}$} & \multicolumn{2}{c|}{$\begin{array}{c}\text { Do you use } \\
\text { this method? }\end{array}$} \\
\hline Cash & Yes & No & Yes & No \\
\hline Credit transfer & & & & \\
\hline Direct debit & & & & \\
\hline Credit card & & & & \\
\hline Debit card & & & & \\
\hline Cheques & & & & \\
\hline Internet banking & & & & \\
\hline Mobile banking & & & & \\
\hline
\end{tabular}

7. How often do you use the following payment instruments? (Select one option for each instrument).

\begin{tabular}{|l|l|l|l|l|l|}
\hline & Very Frequent & Frequently & Sometimes & Rarely & Never \\
\hline Cash & & & & & \\
\hline Credit transfer & & & & & \\
\hline Direct debit & & & & & \\
\hline Credit card & & & & & \\
\hline Debit card & & & & & \\
\hline Cheques & & & & & \\
\hline $\begin{array}{l}\text { Internet } \\
\text { banking }\end{array}$ & & & & & \\
\hline Mobile banking & & & & & \\
\hline
\end{tabular}

8. Why do you use cash as a payment instrument? (You may tick more than one option) 
Cash can be used in more places than cards

Cash is more practical for small value transactions

Cash spending is easier to control, compared to cards

Cash is quicker to use, compared to other payment instruments

It is a habit since I always use cash

I do not use cash

Other (please specify):

9. Why do you use cards as a payment instrument? (You may tick more than one option)

\begin{tabular}{|l|l|}
\hline I do not like to carry cash & \\
\hline Withdrawing cash from ATMs is time consuming & \\
\hline Cards are more practical for large purchases & \\
\hline Cards are easier to use and more convenient & \\
\hline Cards give me the facility to settle the bill at a later date & \\
\hline I do not use cards & \\
\hline Other (please specify): & \\
\hline
\end{tabular}

10. Which is your most preferred payment instrument? (Select one option)
$\square$ Cash
$\square$ Credit transfer
$\square$ Direct debit
$\square$ Credit card
$\square$ Debit card
$\square$ Cheques
$\square$ Internet banking
$\square$ Mobile banking

11. Why is it your preferred instrument? (The most valid reason should be rated as 1 and the least valid reason should be rated as 5 . Leave blank if not applicable.)

\begin{tabular}{|l|l|}
\hline I find it easy and convenient to use & \\
\hline I think it is safe & \\
\hline I do not have to pay any transaction fees & \\
\hline I know exactly how much I would be spending & \\
\hline I have always used this payment instrument & \\
\hline Other (please specify): & \\
\hline
\end{tabular}




\subsection{Section C - Possible future changes in payment habits}

12. Are you aware that you could use your mobile phone as a payment instrument? (Select one option)
$\square$ Yes
$\square$ No

13. Would you consider using your mobile phone as a payment instrument? (Select one option)
$\square$ Yes
$\square$ No

14. If you answer for the previous question was "No", please specify why, by rating 1 to the most valid reason and 5 to the least valid reason.

\begin{tabular}{|l|l|}
\hline I do not always have my mobile phone on me & \\
\hline I feel I would end up spending more money than usual & \\
\hline It will increase my cost for credit & \\
\hline I do not think it is safe enough & \\
\hline My bank does not provide this service & \\
\hline Other (please specify): & \\
\hline
\end{tabular}

15. What would change your mind to use different payment instruments? (Rate 1 to the most valid reason and 5 to the least valid reason)

\begin{tabular}{|l|l|}
\hline Awareness and education about other payment instruments & \\
\hline Small benefits for using internet or cards & \\
\hline More service providers & \\
\hline More places accepting other form of payment instrument & \\
\hline Other (please specify): & \\
\hline
\end{tabular}

16. Would you consider giving up cash and using only other payment instruments in the near future? (Select one option)
$\square$ Yes
$\square$ No 


\section{Biographies}

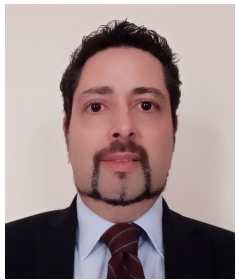

Silvio John Camilleri. Silvio John Camilleri studied banking and finance at the University of Malta and subsequently with the University of London from where he obtained a Masters Degree in financial management. He completed his $\mathrm{PhD}$ programme at the Economics Department of Loughborough University in 2007, where he conducted empirical research on the microstructure of emerging securities markets. He lectures at the Banking and Finance Department of the University of Malta and has published research in various peer-reviewed journals and scholarly collections. Dr. Camilleri formerly worked at the Group Treasury Department of Air Malta Company Ltd. where he was a member of the Investments Committee.

CRediT Statement: Conceptualization, Supervision, Formal Analysis, and Writing Revised Draft.

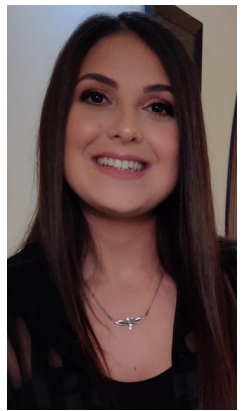

Christabelle Agius. Christabelle Agius was born in Pieta, Malta in 1996. She received the B.Com. (Melit.) in banking and finance, and in management from the University of Malta in 2018, and the B.Com. (Hons)(Melit.) in banking and finance from the University of Malta in 2019. Ms. Agius is employed as an analyst with the Financial Intelligence Analysis Unit, Malta, and was formerly an officer with APS Bank plc, Malta between 2018 to 2019.

CRediT Statement: Data Curation, Investigation, and Writing Original Draft. 